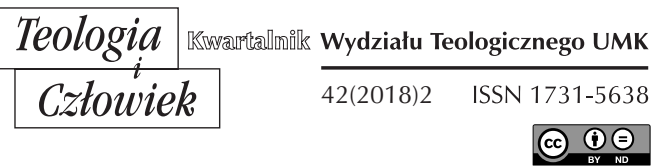

MIROSŁAW MAREK KUCZKOWSKI*

SIERAKOWICE

ORCID: 0000-0001-8799-3786

\title{
UDZIAŁ ŚWIECKICH W KOŚCIELE LOKALNYM I POWSZECHNYM. RADA REGIONU GDAŃSKIEGO FRANCISZKAŃSKKIEGO ZAKONU ŚWIECKICH NA PRZESTRZENI KAPITUŁ W LATACH 1989-2016
}

DOI: http://dx.doi.org/10.12775/TiCz.2018.017

Powołanie do Franciszkańskiego Zakonu Świeckich (Ordo Franciscanus Saecularis) jest wezwaniem do życia Ewangelią we wspólnocie i w świecie ${ }^{1}$. Papież Jan Paweł II w Christifideles laici (ChfL 15) stwierdził: „Dziś wszyscy chrześcijanie powinni jak najpilniej podjąć drogę ewangelicznej odnowy w wielkodusznej odpowiedzi na wezwanie Apostoła do tego, "aby w całym postępowaniu stali się świętymi»"2. Wkroczenie na tę drogę powinno być świadome i opierające się na współpracy z łaską Bożą. Odkrywanie znaczenia powołania właściwego świeckiemu stanowi

* Mirosław Marek Kuczkowski, doktor nauk teologicznych w zakresie historii Kościoła, ur. 1961 r., nie jest pracownikiem naukowym (mir.kuczkowski@gmail.com).

${ }^{1}$ List czterech przełożonych generalnych rodziny franciszkańskiej. Powołanie i misja świeckich franciszkanów w Kościele i świecie, Rzym 1989, s. 23-32.

2 Posynodalna adhortacja apostolska Christifideles laici Ojca świętego Jana Pawła II o powołaniu $i$ misji świeckich $w$ Kościele $i w$ świecie dwadzieścia lat po soborze Watykańskim II, Poznań 1989, s. 37. 
polega na szukaniu „Królestwa Bożego, zajmując się sprawami świeckimi i kierując nimi po myśli Bożej” (LG 31)3. Ważne jest popieranie różnych form stowarzyszeń, bractw i organizacji kościelnych, tych dawno założonych, jak i nowych. Ruchy te nadają Kościołowi dynamiczność, a także są „darem Bożym i przejawem prawdziwej , wiosny Ducha»"4.

Przestrzenią dla życia braterskiego nie są zamknięte pomieszczenia czy kościół jako miejsce spotkania wspólnoty. Tym obszarem jest świat, w którym prowadzone jest również życie duchowe. Wspólnoty braterskie FZŚ dają Kościołowi wzmacnianie katolickości i przeżycie braterstwa powszechnego. Jedną z takich Wspólnot jest m.in. Region Gdański Franciszkańskiego Zakonu Świeckich, który w nowych strukturach ruchu tercjarskiego rozpoczął swoją dziesiątą kadencję służby franciszkanom świeckim. W opracowaniu podjęto próbę przybliżenia jego historii, od daty ustanowienia do czasów obecnych.

\section{CZYM JEST FRANCISZKAŃSKKI ZAKON ŚWIECKICH}

Historia tercjarzy franciszkańskich trwa już prawie osiem wieków ${ }^{5}$ i związana była u swego zarania $\mathrm{z}$ ruchem pokutnym. $\mathrm{Z}$ tych grup wyodrębnili się pokutnicy związani z zakonem franciszkańskim. Na początku również Franciszek i jego bracia, zanim otrzymali zatwierdzenie swojej reguły, nazywali się „pokutnikami z Asyżu”. Dokładna data powstania

${ }^{3}$ Konstytucja dogmatyczna o Kościele, w: Sobór Watykański II, Poznań 1967, s. 136-137: „Pod nazwą świeckich rozumie się tutaj wszystkich wiernych chrześcijan nie będących członkami stanu kapłańskiego i stanu zakonnego prawnie ustawionego w Kościele, mianowicie wiernych chrześcijan, którzy jako wcieleni przez chrzest w Chrystusa, ustanowieni jako Lud Boży i uczynieni na swój sposób uczestnikami kapłańskiego, prorockiego i królewskiego urzędu Chrystusowego, ze swej strony sprawują właściwe całemu ludowi chrześcijańskiemu posłannictwo w Kościele i w świecie”.

${ }^{4}$ Jan Paweł II, Novo Millennio Ineunte, Wrocław 2001, s. 65.

5 A. Brandl, Der Dritte Orden hl. Franziskus von Assisi, w: St. Franziskus 1226-1926, München 1926, s. 75-81; E. Nogaj, Obecność franciszkanów świeckich w świecie, w: Życie i działalność franciszkanów świeckich $w$ świetle Konstytucji Generalnych Franciszkańskiego Zakonu Świeckich, Warszawa 2010, s. 54-55.

${ }^{6}$ L. Iriarte, Historia Franciszkanizmu, Kraków 1998, s. 502; T. Waszecki, Franciszku - jestem, Katowice-Panewniki 1996, s. 6-8. 
Franciszkańskiego Zakonu Świeckich nie jest znana, choć „tradycyjnie przyjął się 1221 rok"7. W tym samym roku został wydany dokument Memoriale propositi odnoszący się do praktyk ascetycznych i regulujący status pokutników w Kościele ${ }^{8}$. Następnie w 1289 r. papież Mikołaj IV (1228-1292) zatwierdził Regułę „życia”. W tym dokumencie wymienia się Franciszka jako „tego Zakonu ustanowiciela”, a tercjarzy nazywa się „Braćmi i Siostrami od Pokuty”. Z czasem zmieniła się nazwa na Trzeci Zakon św. Franciszka. W XIV w. niektóre z grup tercjarzy podejmowały życie wspólnotowe, co dało początek tzw. Trzecim Zakonom Regularnym. W XVII w. Trzeci Zakon skupiał się przy klasztorach franciszkańskich, co znacząco przełożyło się na liczbę członków, lecz niestety zmizerniała postawa duchowa tercjarzy. Odrodzenie Zakonu nastąpiło dopiero w drugiej połowie XIX w. W 1882 r. papież Leon XIII (1878-1903) promulgował encyklikę Auspicato concesum ${ }^{10} \mathrm{z}$ okazji 700. rocznicy urodzin św. Franciszka z Asyżu, w której promował Trzeci Zakon ${ }^{11}$. W następnym roku ogłosił on konstytucję Misercors Dei Filius ${ }^{12}$, dostosowującą Regułę do nowych czasów, łagodząc jej surowość i rewidując niektóre przepisy, jednak nie zmieniając istoty Trzeciego Zakonu. Na tej odnowie nastąpił bardzo dynamiczny rozwój tercjarstwa, który w Polsce przeżywał okres znaczącego rozkwitu w latach międzywojennych (1918-1939) ${ }^{13}$. W 1934 r. Trzeci Zakon liczył 3906368 członków zebranych w prawie 24000 wspólnotach ${ }^{14}$.

7 J. Bar, Tercjarstwo franciszkańskie, Kraków 1945, s. 19.

8 A. Pańczak, Historia III Zakonu Franciszkańskiego, Warszawa-Woźniki 2015, s. $78-83$.

9 Reguła III Zakonu Ś. Franciszka Serafickiego, w: Nowy brewiarz tercyarski, Kraków 1894, s. 82-123.

${ }^{10}$ Encykliki, w: Święty Franciszek $z$ Asyżu i Jego Trzeci Zakon, Wrocław-Kraków 1948, s. 720 .

${ }^{11}$ Przedmowa, w: Nowy Brewiarzyk Tercyarski, Kraków 1910, s. 2.

${ }_{12}$ Konstytucya Ojca św. Leona XIII. o Regule Franciszkanów Trzeciego Zakonu świeckiego, w: Nowy Brewiarzyk Tercyarski, s. 86-124.

${ }^{13}$ M. Kuczkowski, Dzieje Trzeciego Zakonu św. Franciszka z Asyżu na ziemiach polskich $w$ latach 1918-1939 w świetle czasopism tercjarskich, Pelplin 2010, s. 302-303.

${ }^{14}$ Franciszkański Zakon Świeckich, w: Brewiarz Franciszkanów Świeckich, Niepokalanów 2011, s. 15. 
Po II wojnie światowej nadszedł szeroki kryzys w tercjarstwie franciszkańskim, który miał różne przyczyny; jedną z nich był problem tożsamości czy funkcjonowania struktur. W Polsce na niepowodzenia złożyło się m.in. zaniechanie pracy nad wspólnotami tercjarskimi znajdującymi się daleko od klasztorów, a ważnym czynnikiem był także stosunek władzy ludowej do Kościoła.

W 1978 r. papież Paweł VI (1963-1978) listem Seraphicus Patriarcha zatwierdził nową Regułę ${ }^{15}$. Od tego czasu Trzeci Zakon przyjął nazwę Franciszkański Zakon Świeckich. Oprócz Reguły ${ }^{16}$ Zakon posiada obecnie Konstytucje Generalne ${ }^{17}$, Statuty Narodowe ${ }^{18}$ i Rytuał ${ }^{19}$. Opiekę duchową nad franciszkanami świeckimi sprawuje I Zakon franciszkański ${ }^{20}$.

$\mathrm{Na}$ przestrzeni wieków z grona franciszkanów świeckich Kościół wyniósł na ołtarze prawie trzystu świętych i błogosławionych ${ }^{21}$. Do Zakonu wstępowali ludzie różnych stanów, duchowni, królowie, bogaci i biedni ${ }^{22}$.

Życie tercjarzy określa m.in. obecna Reguła: „zachowywać Ewangelię Pana naszego Jezusa Chrystusa, naśladując świętego Franciszka z Asyżu, dla którego Chrystus był natchnieniem i centrum życia w odniesieniu do Boga i ludzi”23.

15 Zatwierdzenie franciszkańskiej Reguły Zakonu Świeckich, w: Pokój i Dobro, Katowice-Panewniki 1992, s. 15-17; P. Mielczarek, Formacja podstawowa we Franciszkańskim Zakonie Świeckich, Warszawa 1995, s. 16-18.

${ }^{16}$ Charyzmat franciszkański dzisiaj na podstawie Reguty, Warszawa 2017, s. 6-7.

${ }_{17}$ Konstytucje Generalne Franciszkańskiego Zakonu Świeckich, Kraków-Warszawa 2001.

18 Statut Wspólnoty Narodowej Franciszkańskiego Zakonu Świeckich w Polsce, Statut Asystencji Duchowej, Statut Młodzieży Franciszkańskiej w Polsce, Warszawa 2003.

19 Rytuał Franciszkańskiego Zakonu Świeckich, Kraków-Warszawa 2001.

${ }^{20}$ V. Redondo, Asystencja Duchowa, w: Dokumenty i materiały V Kapituly Narodowej, Warszawa 2001, s. 20-22.

${ }^{21}$ M. Kuczkowski, Tercjarze św. Franciszka z Asyżu, Pelplin 2014, s. 375-388; L. Iriarte, Historia, s. 570.

22 A. Gemelli, Franciszkanizm, Warszawa 1988, s. 91-93; Zakony franciszkańskie w Polsce, Niepokalanów 1998, cz. 1, s. 54.

${ }^{23}$ Reguła Franciszkańskiego Zakonu Świeckich, Panewniki 1989. 


\section{STRUKTURA FZŚ W OGÓLNOŚCl}

Powołanie nowych struktur w latach dziewięćdziesiątych XX w. nie było czymś nowatorskim, już wcześniej podejmowano próby zespolenia wspólnot w jednolitą strukturę organizacyjną. Tworzono wspólnoty narodowe, które łączyły tercjarzy w jednej obediencji, czy nawet jak w Hiszpanii międzyobedencjalnie ${ }^{24}$. Po wprowadzeniu Reguły w 1978 r. Zakon stał się autonomicznym stowarzyszeniem kościelnym, a tercjarze na całym świecie są widoczną wspólnotą na poziomie międzynarodowym, narodowym, regionalnym i miejscowym.

\subsection{WSPÓLNOTA MIĘDZYNARODOWA}

Posiada osobowość prawną w Kościele i działa zgodnie z własnym Statutem i Konstytucjami (KG 69.1). Władzami wspólnoty są: Kapituła Generalna, Prezydium Rady Międzynarodowej i Rada Międzynarodowa (CIOFS). Prezydium Rady jest organem wykonawczym, który ożywia, koordynuje i kieruje FZŚ na płaszczyźnie międzynarodowej, a także wykonuje decyzje Kapituły Generalnej. Do Rady Międzynarodowej wchodzą członkowie Rad Narodowych. Siedziba Rady Międzynarodowej znajduje się w Rzymie, przy Via Vittorio Putti, 4, $\mathrm{I}^{25}$.

\subsection{WSPÓLNOTA NARODOWA}

Stanowi unię wspólnot miejscowych, zlokalizowanych na terenie państwa, połączonych ze sobą przez wspólnoty regionalne. Jej władzami są: Kapituła Narodowa, Prezydium Rady Narodowej i Rada Narodowa. Do Rady Narodowej, poza członkami Prezydium, wchodzą przełożeni rad regionalnych oraz asystenci narodowi trzech obediencji franciszkańskich: Braci Mniejszych (OFM), Franciszkanów Konwentualnych (OFMConv) i Kapucynów (OFMCap), a także zakonnicy z Trzeciego Zakonu Regularnego (TOR).

\footnotetext{
24 A. Pańczak, Historia III Zakonu, s. 282.

${ }^{25}$ http://www.ciofs.org/portal/index.php/en/ (dostęp 17.02.2017).
} 
W Polsce siedziba Rady Narodowej znajduje się w Warszawie, przy ul. Modzelewskiego $98 \mathrm{a}^{26}$. W $1991 \mathrm{r}$. liczba wspólnot miejscowych w Polsce wynosiła 471, a członków FZŚ było $20341^{27}$.

\subsection{WSPÓLNOTA REGIONALNA}

Jest unią wspólnot miejscowych znajdujących się na określonym terytorium. Zapewnia ona łączność pomiędzy wspólnotami lokalnymi a wspólnotą narodową. Jej władzami są: Kapituła Regionalna i Rada Regionalna. Przy Radzie Regionalnej swoje miejsce mają asystenci regionalni z trzech obediencji I Zakonu i TOR, którzy są mianowani przez kompetentnego wyższego przełożonego.

Wspólnoty Regionalne w Polsce powstały na podstawie Statutu Narodowego przyjętego na II Kapitule Narodowej w 1992 r. $^{28}$, natomiast pierwsze Kapituły Regionalne FZŚ w ramach nowych struktur w Polsce odbyły się w latach 1992-1993. Aktualnie w Polsce istnieje 18 wspólnot regionalnych.

\subsection{WSPÓLNOTA MIEJSCOWA}

Pierwszą i podstawową komórką w FZŚ jest Wspólnota Miejscowa $^{29}$, którą zakłada I Zakon franciszkański lub Trzeci Zakon Regularny (TOR). Do założenia tej wspólnoty upoważniony jest wyższy przełożony zakonny, czyli minister prowincjalny. Wyborów tercjarzy funkcyjnych (Rada Wspólnoty) co trzy lata dokonuje się podczas Kapituły Wspólnoty. Pierwszym odpowiedzialnym za Wspólnotę jest przełożony. Asystencję Wspólnoty prowadzi zakonnik jednej z obediencji franciszkańskiej lub

${ }^{26} \mathrm{http}: / /$ www.fzs.info.pl/radan/radan.html (dostęp 17.02.2017).

27 Dane statystyczne o wspólnotach FZŚ w Polsce, w: Materiały z Kapituły Narodowej Franciszkańskiego Zakonu Świeckich w Polsce, Kraków 1995, s. 62-63.

${ }_{28}$ Protokół z II Kapituły Narodowej Franciszkańskiego Zakonu Świeckich w Polsce w dniach 9-11 października 1992 r. w Kalwarii Zebrzydowskiej, w: Materiały z Kapituły Narodowej Franciszkańskiego Zakonu Świeckich w Polsce, Kraków 1995, s. 37-53.

${ }^{29}$ Franciszkański Zakon Świeckich. Podręcznik dla przełożonych, asystentów i franciszkanów świeckich, Kraków-Warszawa 2000, s. 101-119. 
kapłan diecezjalny mający stosowne upoważnienie wyższego przełożonego zakonnego, a także zgodę biskupa ordynariusza. Asystentem może być również zakonnik innego zgromadzenia posiadający właściwe upoważnienia.

\section{WSPÓLNOTA REGIONU GDAŃSKIEGO}

Zasadniczym zadaniem Rady Narodowej w Polsce po II Kapitule (1992) było przeprowadzenie zmian w organizacji regionów FZŚ. W ówczesnej strukturze funkcjonowało 10 regionów w układzie obediencjalnym. Według nowego Statutu Narodowego utworzono układ regionów według metropolii Kościoła katolickiego. W 1993 r. członkowie Rady Narodowej przewodniczyli wszystkim kapitułom sprawozdawczo-wyborczym przeprowadzonym zgodnie z nowym układem organizacyjnym. W wyniku tego utworzono 14 regionów. Od nowych wyborów władze regionalne rozpoczęły działalność zgodnie z Konstytucjami Generalnymi i Statutem Narodowym.

Przed 1992 r. tercjarze z Pomorza Gdańskiego w większości przynależeli terytorialne do diecezji gdańskiej i chełmińskiej, a organizacyjnie do obediencji Zakonu Braci Mniejszych Konwentualnych (OFMConv) przy Prowincji pw. św. Maksymiliana Marii Kolbego w Gdańsku. W 1992 r. papież Jan Paweł II bullą Totus tuus Poloniae populus dokonał reorganizacji administracyjnej Kościoła w Polsce, w wyniku czego została utworzona metropolia gdańska. Zgodnie $\mathrm{z}$ tym podziałem administracyjnym utworzono Region Gdański FZŚ, który skupił organizacyjnie wspólnoty tercjarskie dawnej diecezji gdańskiej i chełmińskiej oraz nowej diecezji toruńskiej.

W 2004 r. do Regionu należało 39 Wspólnot Miejscowych (Gdańsk - 23, Pelplin - 8, Torun - 8), w których było 1151 profesów wieczystych ${ }^{30}$. W 2007 r. było 40 Wspólnot, w tym cztery nieaktywne (Gdańsk - 23, Pelplin - 9 i Toruń 8) i Region liczył 1044 członków i 13 asystentów

30 Archiwum Rady Regionu Gdańskiego (dalej: ARRG), Sprawozdanie z działalności Rady Regionalnej V kadencji za okres od 1 XII 2001 r. - 27 XI 2004 r., w: Kapituly Regionalne FZŚ Region Gdański 2004 r., 2007 r., 2010 r., 2013 r., s. 3. 
(11 zakonników i 2 księży diecezjalnych) $)^{31}$. W 2013 r. - 40 wspólnot, w tym sześć nieaktywnych (Gdańsk - 19, Pelplin - 7 i Toruń - 8). Tercjarzy było 856 i 15 asystentów (12 zakonników i 3 księży diecezjalnych). Na 31 grudnia 2016 r. do Regionu Gdańskiego należało 713 franciszkanów świeckich ${ }^{32}$.

\subsection{KAPITUŁY REGIONALNE, PODEJMOWANE DZIAŁANIA}

Organem reprezentującym wszystkie wspólnoty istniejące w obszarze wspólnoty regionalnej jest Kapituła, która posiada władzę ustawodawczą i władzę wyborczą. W Statutach Narodowych określone są formalności z nią związane (zwoływanie, skład osobowy, okresowość i kompetencje). W omawianym okresie w Regionie Gdańskim przeprowadzono dziesięć Kapituł, które zostały poniżej przybliżone w układzie chronologicznym, a także ukazano podstawowe działania Rady Regionu w kadencji.

I K a p i t u $ł$ a - 9 grudnia $1989 \mathrm{r}$.

Odbyła się jeszcze według „starej” organizacji FZŚ przy kościele Św. Trójcy w Gdańsku. Kapitule przewodniczył Roch Betlejewski OFMConv, Asystent Prowincjalny i członek Konferencji Asystentów Prowincjalnych (KAP). Siedzibę Rady Regionu ustanowiono przy klasztorze oo. Franciszkanów Konwentualnych w Gdańsku.

W wyniku wyborów powołano pierwszą Radę w składzie:

- przełożony - br. Edward Przytuła z Gdańska,

- zastępca przełożonego - br. Hubert Mayer z Tczewa,

- sekretarz - s. Aleksandra Słowik z Koszalina,

- skarbnik - s. Teresa Sobol z Gdyni,

- radna ds. formacji - s. Agnieszka Szmytkowska z Gdańska.

W trakcie kadencji dokonano zmian w składzie osobowym, tj. radną ds. formacji została Janina Rączka, a zastępcą i sekretarzem s. Teresa Dreścik, obydwie z Gdańska.

${ }^{31}$ Zob. Sprawozdanie z działalności Rady Regionu VI kadencji za okres 27 XI 2004 - 01 XII 2007 r., w: Kapituły Regionalne FZŚ Region Gdański 2004 r., 2007 r., 2010 r., 2013r., s. 4.

${ }^{32}$ Zob. Komunikat nr 3/139 do Wspólnot FZŚ Regionu Gdańskiego, L.dz. 8/17. 
Podejmowane w kadencji działania: poznawano strukturę FZŚ w Regionie, a mianowicie ich liczebność, stan osobowy i mianowano nowe zarządy Wspólnot; inicjowano spotkania Rad Wspólnot Miejscowych, a także ich przełożonych w celu działań organizacyjnych mających na celu tworzenie nowych struktur FZŚ; wprowadzono zjazdy tercjarzy w sanktuarium wejherowskim dla uczczenia Stygmatów św. Franciszka z Asyżu (sobota po 17 września); zainicjowano wydawanie informatora „Dziennik Mniejszy”, który służył do kontaktów ze Wspólnotami.

II K a p i t u $\nmid$ a - 5 grudnia $1992 \mathrm{r}$.

Odbyła się przy kościele Św. Trójcy w Gdańsku. Kapitule przewodniczyła Krystyna Rajzer OFS, z-ca przełożonego Rady Narodowej FZŚ.

Wybrano Radę w składzie:

- przełożona - s. Teresa Nowacka z Gdańska,

- zastępca przełożonej - s. Teresa Zając z Gdańska Nowego Portu,

- sekretarz - s. Zofia Tamborek z Gdańska,

- skarbnik - br. Czesław Kowalski z Gdańska,

- mistrz formacji - s. Janina Rączka z Gdańska,

- radna - s. Jadwiga Cieślak z Gdańska.

Siedzibą Rady pozostał klasztor oo. Franciszkanów Konwentualnych w Gdańsku, a Asystentem Regionu mianowano Kazimierza Kozłowskiego OFMConv z klasztoru gdańskiego.

Podejmowane w kadencji działania: zrealizowano uchwałę II Kapituły Narodowej FZŚ, aby Region objął swym zasięgiem Wspólnoty Miejscowe z terenu Metropolii Gdańskiej, tj. archidiecezji gdańskiej, diecezji pelplińskiej i toruńskiej; na patronkę Regionu Gdańskiego wybrano NMP Niepokalanie Poczętą; dokonano zmiany tytułu informatora $\mathrm{z}$ „Dziennika Mniejszego” na „Fra Max”; zorganizowano pielgrzymki regionalne na Jasną Górę w ramach dorocznego zjazdu FZŚ; zainicjowano Wielkopostny Dzień Skupienia FZŚ w Wejherowie przy kościele oo. Franciszkanów, który później przeniesiono do kościoła Św. Trójcy w Gdańsku (sobota przed trzecią niedzielą Wielkiego Postu).

III K a p i t u $\nmid$ a - 2-4 lutego $1996 \mathrm{r}$.

Odbyła się w Gdańsku pod przewodnictwem Marty Śliwińskiej OFS, delegata Rady Narodowej FZŚ. 
Wybrano Radę w składzie:

- przełożona - s. Teresa Sobol z Gdyni,

- zastępca przełożonej - s. Ryta Gonera z Gdańska,

- sekretarz - s. Elżbieta Hetko z Gdańska Oliwy,

- skarbnik - s. Zofia Tamborek z Gdańska,

- odpowiedzialna za formację - s. Aleksandra Podkowik z Gdańska,

- radna - s. Teresa Nowacka z Gdańska.

Siedzibą Rady został klasztor oo. Franciszkanów Konwentualnych w Gdyni, a Asystentem Regionu mianowano Jacka Kamzelę OFMConv z klasztoru gdyńskiego.

Podejmowane w kadencji działania: rozpoczęto tworzenie dokumentacji niezbędnej do realizacji zadań w Regionie; podjęto rozpoznanie związane $\mathrm{z}$ posiadanymi dokumentami kanonicznego erygowania Wspólnot Miejscowych, a także udzielano pomocy w ich uzyskaniu; wdrażano Konstytucje Generalne FZŚ; kontynuowano spotkania informacyjno-szkoleniowe dla członków Rad Wspólnot, które zorganizowano w Gdańsku, Gdyni, Kartuzach i Toruniu; zainicjowano Dzień Skupienia w Rywałdzie Królewskim i Dzień Skupienia w Chełmnie; w strukturę Regionu włączono Wspólnoty z Chełmna i Wąbrzeźna; zmieniono tytuł informatora regionalnego na „Komunikat”; określono ramowy termin przeprowadzania Kapituł Regionalnych, aby odbywały się przed uroczystością Niepokalanego Poczęcia NMP ${ }^{33}$.

IV K a p i t u $\nmid$ a - 5 grudnia $1998 \mathrm{r}$.

Odbyła się w Gdyni pod przewodnictwem Fryderyka Widery OFS, delegata Rady Narodowej FZŚ w obecności Bolesława Kanacha OFMCap, Asystenta Narodowego FZŚ.

Wybrano Radę w składzie:

- przełożona - s. Teresa Sobol z Gdyni,

- zastępca przełożonej - s. Wanda Kołaczek z Pruszcza Gdańskiego,

- sekretarz - br. Krzysztof Sośnicki z Helu,

- skarbnik - s. Ryta Gonera z Gdańska,

- odpowiedzialna za formację - s. Janina Rączka z Gdańska.

33 Dane pochodzą od s. Teresy Sobol OFS, przełożonej Rady Regionu Gdańskiego w kadencjach: 1996-1998, 1998-2001. 
Siedzibą Rady pozostał klasztor oo. Franciszkanów Konwentualnych w Gdyni, a posługę asystencką przy Radzie pełnili: Jacek Kamzela OFMConv, Jonasz Krefta OFM i Józef Krzaczek OFMCap.

W trakcie kadencji uzupełniono skład Rady Regionu, funkcję sekretarza powierzono s. Bernadecie Nowak z FZŚ przy parafii Bożego Ciała z Gdańska, natomiast odpowiedzialną za formację została s. Maria Grajewska z FZŚ przy parafii Chrystusa Króla w Toruniu.

Podejmowane w kadencji działania: zorganizowano szkolenia (dwa razy w roku) dla osób pełniących funkcje we Wspólnotach Miejscowych; zalecono praktykowanie profesji czasowej jako etapu formacji przed przystąpieniem do profesji wieczystej, uwrażliwiano Wspólnoty na sumienne prowadzenie dokumentacji; w Roku Jubileuszowym zorganizowano wspólne spotkanie trzech trzecich zakonów (franciszkański, dominikański i karmelitański); zorganizowano pielgrzymkę FZŚ do Rzymu ${ }^{34}$.

V K a p i t u ł a - 1 grudnia $2001 \mathrm{r}$.

Odbyła się w Gdyni pod przewodnictwem Joanny Berłowskiej OFS, przełożonej Rady Narodowej FZŚ, w obecności Mariana Jarząbka OFMConv, Asystenta Narodowego FZŚ.

Wybrano Radę w składzie:

- przełożona - s. Wanda Kołaczek z Pruszcza Gdańskiego,

- zastępca przełożonej - s. Daniela Komosińska z Wejherowa,

- sekretarz - s. Bernadeta Nowak z Gdańska Moreny,

- skarbnik - s. Krystyna Kokorczak z Gdańska Przymorza,

- odpowiedzialna za formację - s. Teresa Sobol z Gdyni,

- radny ds. Młodzieży Franciszkańskiej - br. Mirosław Kuczkowski z Sierakowic,

- radna ds. charytatywnych - s. Maria Nakielska z Gdyni.

Siedziba Rady została przeniesiona do klasztoru oo. Kapucynów w Gdańsku przy ul. Wałowej. Skład Asystentów Regionalnych pozostał niezmieniony.

W trakcie kadencji rezygnację złożyli: s. Wanda Kołaczek z funkcji przełożonej Rady Regionu, po której funkcję przejęła s. Daniela Komo-

${ }^{34}$ ARRG, Franciszkański Zakon Świeckich Rada Regionu Gdańskiego 1989: kronika. 
sińska (dotychczasowa z-ca przełożonej Rady Regionu Gdańskiego), s. Maria Nakielska i br. Mirosław Kuczkowski.

Podejmowane w kadencji działania: kontynuowano Regionalne Dni Skupienia w Chełmnie, Gdańsku, Kościerzynie, Rywałdzie Królewskim i Wejherowie; zorganizowano rekolekcje zamknięte u ss. Pallotynek w Gdańsku, które przeprowadzili Asystenci Narodowi FZŚ: Alojzy Pańczak OFM, Bolesław Kanach OFMCap, a także Asystent Regionalny Maksencjusz Walczyński OFM; corocznie organizowano pielgrzymkę na Jasną Górę; w 2002 r. Rada udzieliła pomocy materialnej FZŚ w Kazachstanie; w 2003 r. został utworzony zespół ds. formacji w składzie: s. Teresa Sobol, s. Daniela Komosińska, Jonasz Krefta OFM, a następnie Maksencjusz Walczyński OFM; w 2003 r. członkowie Rady uczestniczyli w jubileuszach: 100-lecia Wspólnoty FZŚ przy kolegiacie św. Mikołaja w Grudziądzu, 80-lecia Wspólnoty FZŚ przy archikatedrze w Gdańsku Oliwie; przeprowadzono 23 Kapituły we Wspólnotach Miejscowych, dokonano 6 wizytacji bratersko-pasterskich; odbyły się dwa szkolenia dla Asystentów i Opiekunów Wspólnot Miejscowych. Frekwencja na zebraniach była niska ${ }^{35}$.

VI K a p i t u $ł$ a - 27 listopada 2004 r.

Odbyła się w Gdańsku Morenie pod przewodnictwem Joanny Berłowskiej OFS, przełożonej Rady Narodowej FZŚ w obecności Mariana Jarząbka OFMConv, Asystenta Narodowego FZŚs ${ }^{36}$.

Wybrano Radę w składzie:

- przełożona - s. Daniela Komosińska z Wejherowa,

- zastępca przełożonej - s. Bernadeta Nowak z Gdańska Moreny,

- sekretarz - s. Krystyna Kokorczak z Gdańska Przymorza,

- skarbnik - s. Alicja Wnuk z Gdańska,

- odpowiedzialna za formacje - s. Teresa Sobol z Gdyni,

${ }^{35}$ Archiwum Rady Regionu Gdańskiego (dalej: ARRG), Sprawozdania $z$ działalności Rady Regionalnej V kadencji za okres od 1 XII 2001 r. - 27 XI 2004, w: Kapituły Regionalne FZŚ Region Gdański 2004 r., 2007 r., 2010 r., 2013 r., s. 1-3.

${ }^{36}$ Zob. Protokół z VI Kapituly Regionu Gdańskiego FZŚ Gdańsk-Morena, kościót Bożego Ciała 27 listopada 2004 r., w: Kapituły Regionalne FZŚ Region Gdański 2004 r., 2007 r., 2010 r., 2013 r., s. 1. 
z Helu,

- radna ds. Młodzieży Franciszkańskiej - s. Bożena Urbanowicz

- radny ds. kontaktów ze wspólnotami - br. Leszek Hołowienko z Gdańska Nowego Portu.

Asystentami Regionalnymi zostali mianowani: Bolesław Konopka OFMCap, Piotr Nowak OFMCap (po zmianie), Jonasz Krefta OFM i Witold Regulski OFMConv.

Siedziba Rady pozostała przy klasztorze oo. Kapucynów w Gdańsku.

Podejmowane w kadencji działania: przeprowadzono szkolenia informacyjno-formacyjne dla przełożonych, sekretarzy i skarbników, a także spotkania szkoleniowe dla Asystentów i Opiekunów Wspólnot Miejscowych; z okazji Świąt Bożego Narodzenia corocznie zorganizowano spotkania opłatkowe, w tym jedno ze spotkań było połączone ze szkoleniem instruktażowym, które przeprowadził Sylwester Haśnik OFM; w 2007 r. zorganizowano spotkanie z pielgrzymami z Białorusi, które miało na celu nawiedzenie okolicznych sanktuariów, zwiedzanie Gdańska jako kolebki „Solidarności” oraz zaprezentowanie walorów turystycznych polskiego wybrzeża; prowadzono comiesięczne dyżury dla tercjarzy w siedzibie Regionu, po których odbywało się spotkanie modlitewne oraz Msza św. w kościele św. Jakuba Apostoła w Gdańsku w intencji powołań do FZŚ; co roku organizowano rekolekcje zamknięte dla chętnych tercjarzy oraz rekolekcje otwarte w Gdańsku i Gdyni (wrzesień, listopad); zorganizowano Dni Skupienia dla FZŚ w Chełmnie, Gdańsku, Kościerzynie, Rywałdzie Królewskim i Wejherowie; każdego roku odbywano pielgrzymkę na Jasną Górę związaną z dorocznym zjazdem FZŚ w Polsce; członkowie Rady Regionu uczestniczyli w rekolekcjach organizowanych przez Radę Narodową w Częstochowie, Tęczynie i w Asyżu ,śladami św. Franciszka”; w trakcie kadencji przeprowadzono we Wspólnotach Miejscowych: 25 Kapituł, 28 wizytacji braterskich i 26 wizytacji pasterskich ${ }^{37}$.

37 Zob. Sprawozdanie z działalności Rady Regionu VI kadencji za okres 27 XI 2004-01 XII 2007 r., w: Kapituły Regionalne FZŚ Region Gdański 2004 r., 2007 r., 2010 r., 2013 r., s. $1-5$. 
VII K a p i t u $ł$ a - 1 grudnia $2007 \mathrm{r}$.

Rozpoczęła się Mszą św. w kościele przy parafii pw. Bożego Ciała w Gdańsku Morenie, której przewodniczył Adam Kalinowski OFMConv, Prowincjał Prowincji św. Maksymiliana w Gdańsku, a współkoncelebransami byli: Alojzy Pańczak OFM - Asystent Narodowy, Jonasz Krefta OFM, Witold Regulski OFMConv, Marek Mietlica OFMCap (Asystenci Regionalni) oraz Asystenci i Opiekunowie Wspólnot Miejscowych.

Przewodniczącym Kapituły był Adam Smoleń OFS, przełożony Rady Narodowej, a Asystentem z ramienia Rady Narodowej Alojzy Pańczak OFM.

Wybrano Radę w składzie:

- przełożona - s. Daniela Komosińska z Wejherowa,

- zastępca przełożonej - s. Bernadeta Nowak z Gdańska Moreny,

- sekretarz - s. Krystyna Kokorczak z Gdańska Przymorza,

- skarbnik - s. Alicja Wnuk z Gdańska,

- mistrz formacji - s. Krystyna Chludzińska z Gdańska Wrzeszcza,

- radny ds. Młodzieży Franciszkańskiej - br. Eligiusz Wirwiński z Helu,

- radny - br. Krzysztof Rynkowski z Grudziądza ${ }^{38}$.

Asystentami Regionalnymi zostali mianowani: Bolesław Konopka OFMCap, Piotr Nowak OFMCap (po zmianie), Jonasz Krefta OFM i Witold Regulski OFMConv.

Siedziba Rady pozostała przy klasztorze oo. Kapucynów w Gdańsku.

Podejmowane $\mathrm{w}$ kadencji działania: przeprowadzono trzy szkolenia dla przełożonych i zastępców Wspólnot Miejscowych oraz jedno dla sekretarzy; wzorem lat ubiegłych Rada kontynuowała cykl szkoleń formacyjnych „Formacja Mistrzów Formacji”, które odbywały się wiosną i jesienią. Łącznie odbyło się sześć spotkań w Gdańsku Matemblewie. Pierwsze spotkanie prowadził zespół z Rady Narodowej w osobach: Joanna Berłowska OFS i Gabriel Kudzia OFM; utworzono wspólny nowicjat przy klasztorach oo. Konwentualnych w Gdyni i Gdańsku; zgodnie z planem, co roku organizowano rekolekcje otwarte w Gdyni i Gdańsku, ku

38 Zob. Protokót VII Kapituly Wyborczej Regionu Gdańskiego Franciszkańskiego Zakonu Świeckich z dnia 01 grudnia 2007 r., w: Kapituły Regionalne FZŚ Region Gdański 2004 r., 2007 r., 2010 r., 2013 r., s. 1-3. 
czci patronki FZŚ w Polsce bł. Anieli Salawy i patronki FZŚ na świecie św. Elżbiety Węgierskiej; zorganizowano rekolekcje zamknięte w Zamku Bierzgłowskim dla Wspólnot z diecezji toruńskiej; w trakcie kadencji przeprowadzono we Wspólnotach Miejscowych: 34 Kapituły, 34 wizytacje braterskie i 29 wizytacji pasterskich ${ }^{39}$.

VIII K a p i t u $\nmid$ a - 27 listopada 2010 r.

Odbyła się w Domu Pielgrzyma przy sanktuarium Matki Bożej Brzemiennej w Gdańsku Matemblewie. Kapituła rozpoczęła się Mszą św., której przewodniczył Mariusz Fałkowski OFMConv, Wikariusz Ministra Prowincji pw. św. Maksymiliana w Gdańsku. W imieniu Rady Narodowej Kapitule przewodniczyła przełożona Joanna Berłowska OFS, w obecności Mariana Jarząbka OFMConv, Asystenta Narodowego.

Wybrano Radę w składzie:

- przełożona - s. Daniela Komosińska z Wejherowa,

- zastępca przełożonej - br. Michał Rynkowski z Grudziądza,

- sekretarz - s. Krystyna Kokorczak z Gdańska Przymorza,

- skarbnik - s. Bernadeta Nowak z Gdańska,

- radna ds. formacji - s. Teresa Sobol z Gdańska,

- radna ds. Młodzieży Franciszkańskiej - s. Maria Zorgiel z Brodnicy,

- radna ds. kontaktów - s. Ewa Janicka z Torunia ${ }^{40}$.

Kolegium Asystentów Regionalnych stanowili: Witold Regulski OFMConv, Marek Metelica OFMCap, Zdzisław Weissbrot OFMCap (po zmianie), Patryk Stryk OFM, Jonasz Krefta OFM (po zmianie).

Z członków Rady powołano zespół ds. formacji w składzie: s. Teresa Sobol, br. Michał Rynkowski i Jonasz Krefta OFM. W trakcie kadencji zmarła s. Krystyna Kokorczak i obowiązki sekretarza powierzono br. Mirosławowi Kuczkowskiemu.

39 Zob. Sprawozdanie z działalności Rady Regionu VII kadencji za okres od 01 XII 2007 do 27 XI 2010, w: Kapituły Regionalne FZŚ Region Gdański 2004 r., 2007 r., 2010 r., 2013 r., s. 3.

40 Tamże, Protokół z przebiegu VIII Kapituły Regionalnej Regionu Gdańskiego Franciszkańskiego Zakonu Świeckich z dnia 27 listopada 2010 roku, w: Kapituły Regionalne FZŚ Region Gdański 2004 r., 2007 r., 2010 r., 2013 r., s. 1. 
Podejmowane działania w kadencji: wydano 16 komunikatów do Wspólnot Miejscowych; przeprowadzono trzy szkolenia dla przełożonych, zastępców i sekretarzy Wspólnot Miejscowych; przeprowadzono co roku dwa szkolenia formacyjne (wiosna, jesień) z cyklu „Formacja Mistrzów Formacji” dla odpowiedzialnych za formację i przełożonych; dla nowicjuszy prowadzono wspólny nowicjat przy klasztorach oo. Franciszkanów Konwentualnych w Gdyni i Gdańsku; co roku zorganizowano rekolekcje zamknięte i otwarte, a także Dni Skupienia; odbywano pielgrzymki na Jasną Górę połączone z dorocznym zjazdem FZŚ w Polsce; zaopatrywano systematycznie Wspólnoty Miejscowe w materiały franciszkańskie i zeszyty do formacji ciągłej ${ }^{41}$.

IX K a p i t u ł a - 23 listopada 2013 r.

Rozpoczęła się Mszą św. w kościele rektorskim pw. św. Jakuba Apostoła w Gdańsku, której przewodniczył Jan Maciejowski OFMConv, Prowincjał Prowincji św. Maksymiliana w Gdańsku, a współkoncelebransami byli: Alojzy Pańczak OFM - Asystent Narodowy, Arkadiusz Czaja OFM, Asystent Prowincjalny, Jonasz Krefta OFM, Witold Regulski OFMConv (Asystenci Regionalni) oraz Asystenci i Opiekunowie Wspólnot Miejscowych.

Kapitule przewodniczyła Emilia Nogaj OFS, delegatka przełożonej Rady Narodowej. Obrady odbyły się w Sali konferencyjnej restauracji La Fontaine w Gdańsku.

Wybrano Radę w składzie:

- przełożony - br. Michał Rynkowski z Grudziądza,

- zastępca przełożonego - br. Zdzisław Górecki z Gdańska,

- sekretarz - br. Wiesław Szwaba z Gdyni

- skarbnik - s. Anna Burczyk ze Starogardu Gdańskiego,

- mistrz formacji - s. Daniela Komosińska z Wejherowa,

- radna regionalna - s. Henryka Sadowska z Kościerzyny,

- radny regionalny - br. Mirosław Kuczkowski z Sierakowic ${ }^{42}$.

${ }^{41}$ Zob. Sprawozdanie z działalności Rady Regionu Gdańskiego VIII za okres od 27 XI 2010 do 23 XI 2013 roku, w: Kapituly Regionalne FZŚ Region Gdański 2004 r., 2007 r., 2010 r., 2013 r., s. 1-4.

${ }_{42}$ Zob. Protokót IX Kapituły Wyborczej FZŚ Regionu Gdańskiego z dn. 23 listopada 2013 r., w: Kapituły Regionalne FZŚ Region Gdański 2004 r., 2007 r., 2010 r., 2013 r., s. 3. 
Podejmowane w kadencji działania: przeprowadzono trzy szkolenia dla przełożonych i zastępców oraz jedno dla sekretarzy w 2014 r. W klasztorze ss. Pallotynek w Gdańsku odbyło się sześć spotkań formacyjnych w cyklu wiosna-jesień; prowadzono wspólny nowicjat Gdańsku; co roku w lutym odbywały się spotkania braterskie z Asystentami i Opiekunami Wspólnot Miejscowych; każdego miesiąca (trzeci czwartek) w siedzibie Rady prowadzono dyżur przez wyznaczonych radnych; kontynuowano cykl rekolekcji w Gdyni, Gdańsku, Zamku Bierzgłowskim i Laskowicach Pomorskich; regularnie w ciągu roku odbywały się Dni Skupienia; w 2014 r. odbyło się spotkanie „Eufra” - zjazd franciszkanów świeckich z Europy, którego gospodarzem był Region Gdański. W spotkaniu udział wzięli przedstawiciele z jedenastu krajów. W programie było zwiedzanie Gdańska, a także ziemi kaszubskiej; co roku organizowano pielgrzymkę na Jasną Górę połączoną z Ogólnopolskim Zjazdem FZŚ; w trakcie kadencji przeprowadzono we Wspólnotach Miejscowych: 32 Kapituły Wyborcze i 23 wizytacje bratersko-pasterskie; wydano 21 komunikatów do Wspólnot Miejscowych ${ }^{43}$.

X K a p i t u $\nmid$ a - 26 listopada 2016 r.

Rozpoczęła się Mszą św. w kościele rektorskim pw. św. Jakuba Apostoła w Gdańsku, której przewodniczył Zdzisław Duma OFMCap, Asystent Regionalny FZŚ i gwardian klasztoru oo. Kapucynów, a współkoncelebransami byli: Jonasz Krefta OFM, Dacjusz Pyszka OFM, Edward Kryger OFMCap i ks. Zbigniew Orlikowski z Tczewa.

Przewodniczącym Kapituły był Zygfryd Smarzyk OFS, delegat przełożonej Rady Narodowej, a Asystentem z ramienia Rady Narodowej Nikodem Sobczyński OFM.

Wybrano Radę w składzie:

- przełożony- br. Michał Rynkowski z Grudziądza,

- zastępca przełożonego - br. Zdzisław Górecki z Gdańska,

- sekretarz - br. Wiesław Szwaba z FZŚ,

- skarbnik - s. Anna Burczyk ze Starogardu Gdańskiego,

- mistrz formacji - s. Daniela Komosińska z Wejherowa,

43 Zob. Sprawozdanie z działalności Rady Regionu Gdańskiego IX kadencji za okres od 23 XI 2013 do 26 XI 2016 roku, w: Kapituły Regionalne FZŚ Region Gdański 2004 r., 2007 r., 2010 r., 2013 r., s. 1-3. 
- radna regionalna - s. Julianna Kępska z Torunia,

- radna regionalna - s. Halina Poćwiardowska z Brodnicy.

\section{WIZYTACJE RADY REGIONU}

„Wizytacja braterska jest momentem komunii, wyrazem posługi i konkretnego zainteresowania odpowiednich świeckich na różnych stopniach, aby wspólnota wzrastała i była wierna swojemu powołaniu" (KG 94.1) ${ }^{44}$.

„Wizytacja [pasterska] jest uprzywilejowanym momentem komunii z Pierwszym Zakonem i TOR. Jest ona przeprowadzana w imieniu Kościoła oraz służy zapewnieniu i wspieraniu zachowania Reguły i Konstytucji, i wierności charyzmatowi franciszkańskiemu. Będzie się odbywać w poszanowaniu organizacji i prawa własnego FZŚ” (KG 95.1) ${ }^{45}$.

Wizytację przeprowadzają dwaj wizytatorzy: świecki i zakonny. Wizytacja braterska i pasterska może być przeprowadzona równocześnie. Wizytator sprawdza akta Wspólnoty, a także ocenia jakość posługi odpowiedzialnych we Wspólnocie oraz rozważa ewentualne problemy i sposób ich rozwiązania. Wizytacji dokonuje Rada wyższego stopnia.

W Radzie Regionu Gdańskiego przeprowadzono następujące wizytacje bratersko-pasterskie (podano datę wizytacji i wizytatorów) ${ }^{46}$ :

- 21-22.11.2003 r., Joanna Berłowska OFS, Marian Jarząbek OFMConv,

- 1-2 grudnia 2006 r., Joanna Berłowska OFS, Bolesław Kanach OFMCap,

- 27 czerwca 2009 r., br. Adam Smoleń OFS, Elizeusz Martynów OFMCap,

- 29-30 czerwca 2012 r., Emilia Nogaj OFS, Alojzy Pańczak OFM,

- 10-11 lipca 2015 r., Maria Kos OFS, Gabriel Kudzia OFM ${ }^{47}$.

${ }^{44}$ Konstytucje Generalne, s. 87.

${ }^{45}$ Konstytucje Generalne, s. 89.

${ }^{46}$ Możliwe jest, że wizytacji było więcej. Wymieniono jedynie te, które zapisano w dokumentach.

${ }^{47}$ ARRG, Wizytacje Regionu Gdańskiego FZŚ: Dane uzyskane z kwestionariuszy wizytacyjnych. 


\section{ZAKOŃCZENIE}

Podczas synodu biskupów w 1987 r., który zajmował się „Powołaniem i misją świeckich w Kościele i w świecie”, przypomniano wezwanie Soboru Watykańskiego II, aby świeccy aktywnie uczestniczyli w życiu Kościoła miejscowego, a także Kościoła powszechnego (ChL 25) ${ }^{48}$ oraz trwali w jedności z Kościołem i jego duchowieństwem.

Reguła Franciszkańskiego Zakonu Świeckich zachęca i trafnie określa drogę postępowania, jaką winni kierować się tercjarze: „Natchnieni przez św. Franciszka i z nim powołani do odnowy Kościoła, niech starają usilnie, aby żyć w pełnej łączności z Papieżem, Biskupami i Kapłanami, podtrzymując otwarty i ufny dialog, który przynosi obfite owoce apostolskie"49. Na kanwie ducha wspólnotowego i dialogu tworzy się współpraca z innymi grupami i stowarzyszeniami w Kościele, a braterstwo ewangeliczne przełamuje podziały między ludźmi, aby tworzyć „nowego człowieka”.

Streszczenie. Historia tercjarzy franciszkańskich trwa już prawie osiem wieków i związana była u swego zarania z ruchem pokutnym. Za datę powstania Franciszkańskiego Zakonu Świeckich tradycyjnie przyjmuje się 1221 r. Papież Paweł VI w 1978 r. listem Seraphicus Patriarcha zatwierdził nową Regułę dla tercjarzy. Po jej wprowadzeniu Zakon stał się autonomicznym stowarzyszeniem kościelnym, a tercjarze na całym świecie są widoczną wspólnotą na poziomie międzynarodowym, narodowym, regionalnym i miejscowym.

Wspólnoty braterskie FZŚ dają Kościołowi wzmacnianie katolickości i przeżycie braterstwa powszechnego. Jedną z takich Wspólnot tworzy Region Gdański, który w nowych strukturach ruchu tercjarskiego rozpoczął swoją dziesiątą kadencję służby franciszkanom świeckim. Region skupia Wspólnoty tercjarskie z archidiecezji gdańskiej, diecezji pelplińskiej i toruńskiej. W opracowaniu podjęto próbę przybliżenia jego historii, od daty ustanowienia do czasów obecnych.

Słowa kluczowe: Region Gdański; św. Franciszek; Reguła; Zakon; tercjarz.

Abstract. The Participation of the Laity in the Local and Common Church. Council of Gdańsk Region and the Secular Franciscan Order Over the Chapters of 1989-2016. The history of Franciscan tertiary has lasted for over eight centuries and has

48 Posynodalna adhortacja apostolska Christifideles laici, s. 63-66.

49 Reguła Franciszkańskiego Zakonu Świeckich, w: Brewiarz Franciszkanów Świeckich, Niepokalanów 2011, s. 29. 
always been connected with penitential movement. The tradition tells that the Franciscan Order was founded in 1221. The Pope Paul VI confirmed the rule for the tertiaries with his letter Seraphicus Patriarcha. After its introduction, the Order became the autonomous association of church and the tertiaries from all the world were the noticeable community on the international, national, regional and local level.

Fraternities of the secular Franciscan Order provide the church the strengthening of catholicity and the unique experience of universal brotherhood. The region of Gdańsk has developed one of such communities. Nowadays, in the new structures of the tertiary movement, the Gdańsk community has started its tenth term of office in order to serve the secular Franciscans. The region includes the tertiary communities from Gdańsk archdiocese, diocese of both Pelplin and Torun. This study attempts to present its history from the date of foundation to the present time.

Key words: Gdansk order region; St. Francis; the Rule; Tertiary.

\section{BIBLIOGRAFlA}

ARRG, Franciszkański Zakon Świeckich Rada Regionu Gdańskiego 1989 [kronika].

ARRG, Kapituly Regionalne FZŚ Region Gdański 2004 r., 2007 r., 2010 r., 2013 r.,: Protokót z VI Kapituly Regionu Gdańskiego FZŚ Gdańsk-Morena, kościót Bożego Ciała 27 listopada 2004 r.; Protokół VII Kapituły Wyborczej Regionu Gdańskiego Franciszkańskiego Zakonu Świeckich z dnia 01 grudnia 2007r.; Protokół z przebiegu VIII Kapituły Regionalnej Regionu Gdańskiego Franciszkańskiego Zakonu Świeckich $z$ dnia 27 listopada 2010 roku; Protokół IX Kapituły Wyborczej FZŚ Regionu Gdańskiego z dn. 23 listopada 2013 r.; Sprawozdania z działalności Rady Regionalnej $V$ kadencji za okres od 1 XII 2001 r. - 27 XI 2004; Sprawozdanie z działalności Rady Regionu VI kadencji za okres 27 XI 2004 - 01 XII 2007 r.; Sprawozdanie $z$ działalności Rady Regionu VII kadencji za okres od 01 XII 2007 do 27 XI2010; Sprawozdanie z działalności Rady Regionu Gdańskiego VIII za okres od 27 XI 2010 do 23 XI 2013 roku; Sprawozdanie z działalności Rady Regionu Gdańskiego IX kadencji za okres od 23 XI 2013 do 26 XI 2016 roku.

ARRG, Komunikat nr 3/139 do Wspólnot FZŚ Regionu Gdańskiego, L.dz. 8/17.

ARRG, Wizytacje Regionu Gdańskiego FZŚ.

Bar J., Tercjarstwo franciszkańskie, Kraków 1945, s. 19.

Brandl A., Der Dritte Orden hl. Franziskus von Assisi, w: St. Franziskus 1226-1926, München 1926, s. 75-81.

Charyzmat franciszkański dzisiaj na podstawie Reguły, Warszawa 2017, s. 6-7.

Dane statystyczne o wspólnotach FZŚ w Polsce, w: Materiały z Kapituły Narodowej Franciszkańskiego Zakonu Świeckich w Polsce, Kraków 1995, s. 62-63.

Encykliki, w: Święty Franciszek z Asyżu i Jego Trzeci Zakon, Wrocław-Kraków 1948, s. 7-20. 
Franciszkański Zakon Świeckich, w: Brewiarz Franciszkanów Świeckich, Niepokalanów 2011, s. 15.

Franciszkański Zakon Świeckich. Podręcznik dla przełożonych, asystentów i franciszkanów świeckich, Kraków-Warszawa 2000, s. 101-119.

Gemelli A., Franciszkanizm, Warszawa 1988, s. 91-93.

Iriarte L., Historia Franciszkanizmu, Kraków 1998, s. 502.

Jan Paweł II, Novo Millennio Ineunte, Wrocław 2001, s. 65.

Konstytucja dogmatyczna o Kościele, w: Sobór Watykański II, Poznań 1967, s. 136-137 .

Konstytucje Generalne Franciszkańskiego Zakonu Świeckich, Kraków-Warszawa 2001.

Konstytucya Ojca św. Leona XIII. o Regule Franciszkanów Trzeciego Zakonu świeckiego, w: Nowy Brewiarzyk Tercyarski, Kraków 1910, s. 86-124.

Kuczkowski M., Dzieje Trzeciego Zakonu św. Franciszka z Asyżu na ziemiach polskich w latach 1918-1939 w świetle czasopism tercjarskich, Pelplin 2010, s. 302-303.

Kuczkowski M., Tercjarze św. Franciszka z Asyżu, Pelplin 2014, s. 375-388.

List czterech przełożonych generalnych rodziny franciszkańskiej. Powołanie i misja świeckich franciszkanów w Kościele i świecie, Rzym 1989, s. 23-32.

Mielczarek P., Formacja podstawowa we Franciszkańskim Zakonie Świeckich, Warszawa 1995, s. $16-18$.

Nogaj E., Obecność franciszkanów świeckich w świecie, w: Życie i działalność franciszkanów świeckich w świetle Konstytucji Generalnych Franciszkańskiego Zakonu Świeckich, Warszawa 2010, s. 54-55.

Pańczak A., Historia III Zakonu Franciszkańskiego, Warszawa-Woźniki 2015, s. 78-83.

Posynodalna adhortacja apostolska Christifideles laici Ojca świętego Jana Pawła II o powołaniu i misji świeckich $w$ Kościele $i w$ świecie dwadzieścia lat po soborze Watykańskim II, Poznań 1989, s. 37, 63-66.

Protokół z II Kapituly Narodowej Franciszkańskiego Zakonu Świeckich w Polsce w dniach 9-11 października 1992 r. w Kalwarii Zebrzydowskiej, w: Materiały z Kapituły Narodowej Franciszkańskiego Zakonu Świeckich w Polsce, Kraków 1995, s. $37-53$.

Przedmowa, w: Nowy Brewiarzyk Tercyarski, Kraków 1910, s. 2.

Redondo V., Asystencja Duchowa, w: Dokumenty i materiały V Kapituly Narodowej, Warszawa 2001, s. 20-22.

Reguła Franciszkańskiego Zakonu Świeckich, Panewniki 1989.

Reguła Franciszkańskiego Zakonu Świeckich, w: Brewiarz Franciszkanów Świeckich, Niepokalanów 2011, s. 29.

Reguła III Zakonu Ś. Franciszka Serafickiego, w: Nowy brewiarzy tercyarski, Kraków 1894, s. $82-123$.

Rytuał Franciszkańskiego Zakonu Świeckich, Kraków-Warszawa 2001.

Statut Wspólnoty Narodowej Franciszkańskiego Zakonu Świeckich w Polsce, Statut Asystencji Duchowej, Statut Młodzieży Franciszkańskiej w Polsce, Warszawa 2003.

Waszecki T., Franciszku - jestem, Katowice-Panewniki 1996, s. 6-8. 
Zakony franciszkańskie w Polsce, Niepokalanów 1998, cz. 1, s. 54.

Zatwierdzenie franciszkańskiej Reguły Zakonu Świeckich, w: Pokój i Dobro, Katowice-Panewniki 1992, s. 15-17.

\section{Źródła internetowe:}

http://www.ciofs.org/portal/index.php/en/ (dostęp 17.02.2017).

http://www.fzs.info.pl/radan/radan.html (dostęp 17.02.2017). 